\title{
Meso- and bathypelagic distribution and abundance of chaetognaths in the Atlantic sector of the Southern Ocean
}

\author{
Svenja Kruse · Ulrich Bathmann • Thomas Brey
}

Received: 5 December 2008 / Revised: 3 April 2009 / Accepted: 3 April 2009 / Published online: 19 April 2009

(C) Springer-Verlag 2009

\begin{abstract}
We conducted multinet sampling during winter and summer in the Southern Ocean (Atlantic sector) to investigate the effect of water mass, season and water depth on abundance and species composition of meso- and bathypelagic chaetognaths. Eukrohnia hamata (mean 115 ind. $1,000 \mathrm{~m}^{-3}$ ) and Sagitta marri (mean 51 ind. 1,000 $\mathrm{m}^{-3}$ ) were dominant, complemented by E. bathypelagica (mean 19 ind. $1,000 \mathrm{~m}^{-3}$ ) and E. bathyantarctica (mean 19 ind. $1,000 \mathrm{~m}^{-3}$ ) below $1,000 \mathrm{~m}$. A further six species were identified, among them the rare bathypelagic species Heterokrohnia fragilis and the subtropical Eukrohnia macroneura that is new to the Antarctic. Water depth and season were the principal determinants of abundance and species composition patterns, indicating vertical seasonal migration and vertical segregation of species. The life cycles of E. hamata and $S$. marri were studied additionally. Their maturity stages were vertically segregated and prolonged reproductive periods are suggested for both species.
\end{abstract}

Keywords Chaetognatha $\cdot$ Antarctica $\cdot$ Bathypelagial . Distribution $\cdot$ Abundance $\cdot$ Life cycle

\section{Introduction}

Chaetognaths represent a major component of the world's marine zooplankton. In the Southern Ocean they contribute

\footnotetext{
S. Kruse $(\bowtie) \cdot$ U. Bathmann · T. Brey

Alfred Wegener Institute for Polar and Marine Research, Am Handelshafen 12, 27570 Bremerhaven, Germany

e-mail: Svenja.Kruse@awi.de

U. Bathmann

e-mail: Ulrich.Bathmann@awi.de

T. Brey

e-mail: Thomas.Brey@awi.de
}

significantly to the total zooplankton stock, at times reaching up to $30 \%$ of the total zooplankton abundance (Piatkowski 1985; Froneman and Pakhomov 1998; Pakhomov et al. 1999, 2000). As main predators of copepods (Øresland 1990, 1995) chaetognaths may consume up to $5.2 \%$ of the standing stock per day (Froneman and Pakhomov 1998). Hence, they are of great importance for the energy transfer from copepods to higher trophic levels (Bone et al. 1991) and may contribute considerably to the vertical carbon flux (Dilling and Alldredge 1993).

Detailed studies on the Antarctic chaetognath fauna started at the beginning of the twentieth century (e.g. by Ritter-Záhony 1911), already more than 100 years after the first publication concerning a chaetognath (Slabber 1775, reviewed by Bone et al. 1991). So far, investigations on Antarctic chaetognath ecology focused on the austral summer and on the upper $500 \mathrm{~m}$ (e.g. Timonin 1968; Terazaki 1989; Bielecka and Zmijewska 1993; Blachowiak-Samolyk et al. 1995) to 1,000 m (Thiel 1938; Duró et al. 1999; Duró and Gili 2001; Johnson and Terazaki 2004) of the water column. Despite the extensive data on Antarctic chaetognath distribution and abundance below 1,000 m of David (1958a, 1965) and Alvariño et al. (1983a, b), our knowledge of the deep water chaetognath ecology is still fragmentary. There is a general lack of deep samples, and, quite often, unsuitable large mesh sizes were used (Hagen 1985; Duró and Gili 2001). Consequently, reliable quantitative data are rare, and hitherto a number of bathypelagic species are known from very few specimens only (Terazaki 1991).

One major objective of our study was to evaluate the effects of water mass (Polar Frontal Zone, Weddell Gyre, Coastal Current), of season (summer-winter) and of water depth (4 depth strata) on abundance and species composition of meso- and bathypelagic chaetognaths in the Atlantic sector of the Southern Ocean. Furthermore, the two expeditions 
provided a unique opportunity for seasonal deep sampling with small mesh sizes $(100 \mu \mathrm{m})$ in the same area, thus allowing an investigation of the complete community composition covering the entire size range and all maturity stages of the predominant chaetognath species. Detailed life cycle analyses were possible, and contribute to our knowledge on chaetognath biology in the Southern Ocean.

\section{Materials and methods}

Field sampling

Chaetognaths were sampled during two expeditions in the Lazarev Sea with the RV Polarstern, expedition ANT 23-6 in Antarctic winter 2006 (17 June-21. August 2006), and expedition ANT 24-2 in Antarctic summer 2007/2008 (28 November 2007-04 February 2008). Stratified sampling with a multinet was performed at 28 stations in winter (between $60^{\circ}$ and $68^{\circ} 30^{\prime} \mathrm{S}$ ) and at 15 stations in summer (at $52^{\circ} \mathrm{S}$ and between $62^{\circ}$ and $70^{\circ} \mathrm{S}$ ) along three transects $\left(3^{\circ} \mathrm{W}, 3^{\circ} \mathrm{E}\right.$ and $\left.0^{\circ} \mathrm{E}\right)$. This multiple opening/closing net (opening size: $0.25 \mathrm{~m}^{2}$ ) was equipped with five nets with $100-\mu \mathrm{m}$ mesh size and sampled the following standard depth intervals: 2,000-1,500, 1,500-1,000, 1,000-750, 750-500, 500-0 m. Exceptions from the standard depths were made at three stations during ANT 23-6 (at $61^{\circ} 30^{\prime} \mathrm{S}$ and $62^{\circ} \mathrm{S} 3^{\circ} \mathrm{E}$ to $3,000 \mathrm{~m}$, at $65^{\circ} \mathrm{S} 3^{\circ} \mathrm{E}$ to $1,250 \mathrm{~m}$ depth) and at one during ANT $24-2$ (at $70^{\circ} \mathrm{S} 3^{\circ} \mathrm{W}$ to $1,500 \mathrm{~m}$ depth). The winter station around $66^{\circ} \mathrm{S} 0^{\circ} \mathrm{E}$ was a 5-days station, located at a drifting ice camp.

As the abundance of chaetognaths in the epipelagial is already well known and as we are particularly interested in meso- and bathypelagic chaetognaths, we neglected the 500-0 m depth layer in the present study.
Our sampling scheme covered three different water masses, the Polar Frontal Zone (PFZ) with two stations at $52^{\circ} \mathrm{S}$ in summer, the Weddell Gyre (WG), water mass between $60^{\circ} \mathrm{S}$ and $68^{\circ} \mathrm{S}$, and the Coastal Current (CC) at and south of $68^{\circ} \mathrm{S}$. The different pelagic zones are defined as follows: epipelagic $(0-500 \mathrm{~m})$, mesopelagic (500$1,000 \mathrm{~m}$ ) and bathypelagic (below 1,000 m).

Laboratory methods and data processing

Directly after sampling, chaetognaths were sorted. The specimens were counted, identified to species level and their body length (without tail fin) was measured under a stereomicroscope (Olympus SZX12) to the nearest $0.5 \mathrm{~mm}$. During the winter expedition, a part of each sample was immediately preserved in formaldehyde ( $4 \%$ final concentration, buffered with hexamine) and measured later in the home laboratory. To compensate for preservation induced shrinkage, we computed shrinkage factors for the dominant species from repeated length measurements of fresh and subsequently formaldehyde preserved specimens collected during the summer expedition. This allowed the comparison of lengths between formaldehyde preserved and frozen chaetognaths.

Taxonomic identification was conducted to species level under a stereomicroscope (see above) and a microscope (Zeiss Axioskop 2 plus) using the relevant literature (Alvariño 1969; O'Sullivan 1982; Casanova 1986, 1999; Kapp 1991a). Damaged chaetognaths, that could not be identified to species level, or smaller Eukrohnia individuals ( $<10 \mathrm{~mm})$ were pooled as Sagitta or Eukrohnia spp., respectively. The two most abundant species, Eukrohnia hamata Möbius 1875 and Sagitta marri David 1956, were classified into five maturity stages according to Kramp (1939) and David (1955) (Table 1).

Table 1 Maturity stage classification of Eukrohnia hamata and Sagitta marri according to Kramp (1939) and David (1955)

\begin{tabular}{|c|c|c|c|c|}
\hline \multirow[t]{2}{*}{ Stage } & \multicolumn{2}{|c|}{ Eukrohnia hamata (from Kramp 1939) } & \multicolumn{2}{|c|}{ Sagitta marri (from David 1955 for Sagitta gazellae) } \\
\hline & Male gonads & Female gonads & Male gonads & Female gonads \\
\hline I & Unripe & Unripe & $\begin{array}{l}\text { Tail segment empty; } \\
\text { rudiments of testes present }\end{array}$ & Ovaries not visible or rudimentary \\
\hline II & $\begin{array}{l}\text { Tail containing more } \\
\text { or less sperm }\end{array}$ & All eggs small & $\begin{array}{l}\text { Tail segment opaque; } \\
\text { seminal vesicles may show } \\
\text { as small protuberances }\end{array}$ & Ovaries short and thin; eggs small \\
\hline III & Sperm evacuated & $\begin{array}{l}\text { All eggs small, } \\
\text { seminal receptacles } \\
\text { filled with sperm }\end{array}$ & $\begin{array}{l}\text { Seminal vesicles fully formed; } \\
\text { tail segment empty }\end{array}$ & Ovaries thin, but variable in length \\
\hline IV & Sperm evacuated & Ovaries filled with ripe eggs & $\begin{array}{l}\text { Seminal vesicles usually } \\
\text { discharged }\end{array}$ & Ovaries thick and long; eggs enlarged \\
\hline V & Sperm evacuated & $\begin{array}{l}\text { Eggs evacuated, receptacles } \\
\text { still containing sperm }\end{array}$ & Sperm discharged & $\begin{array}{l}\text { Eggs discharged; remnants of ovaries } \\
\text { are irregular masses sometimes } \\
\text { spread into the tail segment }\end{array}$ \\
\hline
\end{tabular}


In the genus Eukrohnia, we pooled all individuals smaller than $6 \mathrm{~mm}$ (and usually larger than $2.5 \mathrm{~mm}$ ) belonging to stage 1 into the group "Eukrohnia juveniles". The small individuals of Eukrohnia bathyantarctica David 1958 could easily be identified, but the juveniles of E. hamata and of E. bathypelagica Alvariño 1962 were difficult to distinguish, owing to lack of characters and congruence of size. Specific characteristics of adults such as a flabby, translucent body or coiled immature ovaries and a proportionally longer tail (described by Alvariño 1962) are not yet developed in juveniles of $5 \mathrm{~mm}$ length and this results in problems of species identification. Because of the absence of stages 4 and 5 individuals of $E$. hamata in summer, we suggest that the remaining juveniles are E. bathypelagica, as stage 4 and 5 individuals of this species were observed (Kruse 2009). It is possible, however, that we just missed the mature E. hamata adults (as discussed below).

Numbers per sample are standardized to number of individuals per $1,000 \mathrm{~m}^{3}$. For the 5-days winter station the geographical and vertical abundance data are averaged over all eight sub-stations.

\section{Statistical analyses}

To evaluate differences in species composition, we applied a cluster analysis (e.g. Everitt et al. 2001) to the species $\times$ abundance matrix $(9$ species $\times 170$ samples, see Sect. "Results"). The resulting cluster identities were taken as representative for distinct species assemblages. Nominal logistic regression (e.g. Agresti 2002) was used to identify relationships between cluster identity and water mass, season and depth layer. Abundance values were square-root transformed prior to analysis to reduce the influence of outliers. We applied hierarchical clustering and compared several linkage methods (average, centroid, complete, Ward's minimum variance) to check for consistency of results.

We analysed abundance data at the family level (Sagittoidea, i.e. all species present), at the genus level (Eukrohnia and Sagitta) and at the species level (abundant species only, see below). Maturity stages (mean stage per sample) were analysed for E. hamata and S. marri. Data were BoxCox transformed to achieve normality and homogeneity of variances and subjected to a full factorial three-way ANOVA (abundance/mean stage versus water mass and season and depth and water mass $\times$ depth and season $\times$ depth) with subsequent post hoc test on differences between means ( $\alpha=0.05$, Sokal and Rohlf 1981). The interaction term water mass $\times$ season was not tested, as there are no winter samples from the PFZ.

Additionally, a full factorial two-way ANOVA (length versus maturity stage and season and maturity stage $\times$ season) was applied to analyse differences in length in E. hamata and S. marri (data were treated as mentioned for the previous ANOVA). Seasonal differences between the length-frequency distributions were analysed by means of a Kolmogorow-Smirnow test in both species.

All statistical analyses were performed with the software package JMP (SAS Inc).

\section{Results}

Influence of formaldehyde on chaetognath body length

Due to the preservation of the samples with formaldehyde (4\% final concentration, buffered with hexamine, 4 months exposure) the chaetognath body length shrunk up to $21 \%$. Shrinkage amounted to $3.67 \%(\mathrm{SD} \pm 2.51, n=104)$ in Eukrohnia hamata, to $5.37 \%( \pm 3.38, n=93)$ in E. bathyantarctica, and to $6.23 \%( \pm 3.84, n=79)$ in E. bathypelagica irrespective of length and maturity stage. Highest reduction of $7.17 \%( \pm 3.97, n=87)$ in length was measured for $S$. marri. The chaetognaths shrunk particularly in the first days and weeks. However, they kept shrinking very slowly even after 4 months of formaldehyde preservation (personal observation).

Geographical and vertical chaetognath distribution

We were able to identify ten different species from three genera in our samples: E. hamata, E. bathypelagica, E. bathyantarctica, E. macroneura Casanova 1986, Heterokrohnia fragilis Kapp and Hagen 1985, H. mirabilis Ritter-Záhony 1911, S. marri, S. macrocephala Fowler 1905, S. maxima Conant 1896 and S. gazellae RitterZáhony 1909. E. hamata and $S$. marri were the two most abundant of these species, independent of the water masses (Tables 2, 3, 4).

Eukrohnia juveniles were very frequent in summer, and for a better comparison of seasons they were excluded from the Figs. 1b, 2b, 3b, 4b that display summer data but are presented separately (Fig. 1c). During winter Eukrohnia juveniles were extremely rare and thus are not presented separately. Juveniles of other species, e.g. Sagitta marri, were readily identified and not treated separately.

The mean chaetognath abundance of the 500 to $2,000 \mathrm{~m}$ depth stratum ranged from 58 ind. $1,000 \mathrm{~m}^{-3}\left(61^{\circ} 30^{\prime} \mathrm{S}\right.$ $\left.3^{\circ} \mathrm{E}\right)$ to 443 ind. $1,000 \mathrm{~m}^{-3}\left(65^{\circ} \mathrm{S} 3^{\circ} \mathrm{E}\right.$; Fig. 1a) in winter, and from 91 ind. $1,000 \mathrm{~m}^{-3} \quad\left(64^{\circ} 30^{\prime} \mathrm{S} \quad 0^{\circ} \mathrm{E}\right)$ to 508 ind. $1,000 \mathrm{~m}^{-3}\left(70^{\circ} \mathrm{S} 3^{\circ} \mathrm{W}\right)$ in summer (without Eukrohnia juveniles; Fig. 1b). Juvenile Eukrohnia ranged from 2 ind. $1,000 \mathrm{~m}^{-3}\left(69^{\circ} \mathrm{S} 0^{\circ} \mathrm{E}\right)$ to 880 ind. $1,000 \mathrm{~m}^{-3}\left(66^{\circ} \mathrm{S}\right.$ $3^{\circ} \mathrm{E}, 62^{\circ} \mathrm{S} 0^{\circ} \mathrm{E}$, Fig. 1c) in summer. 


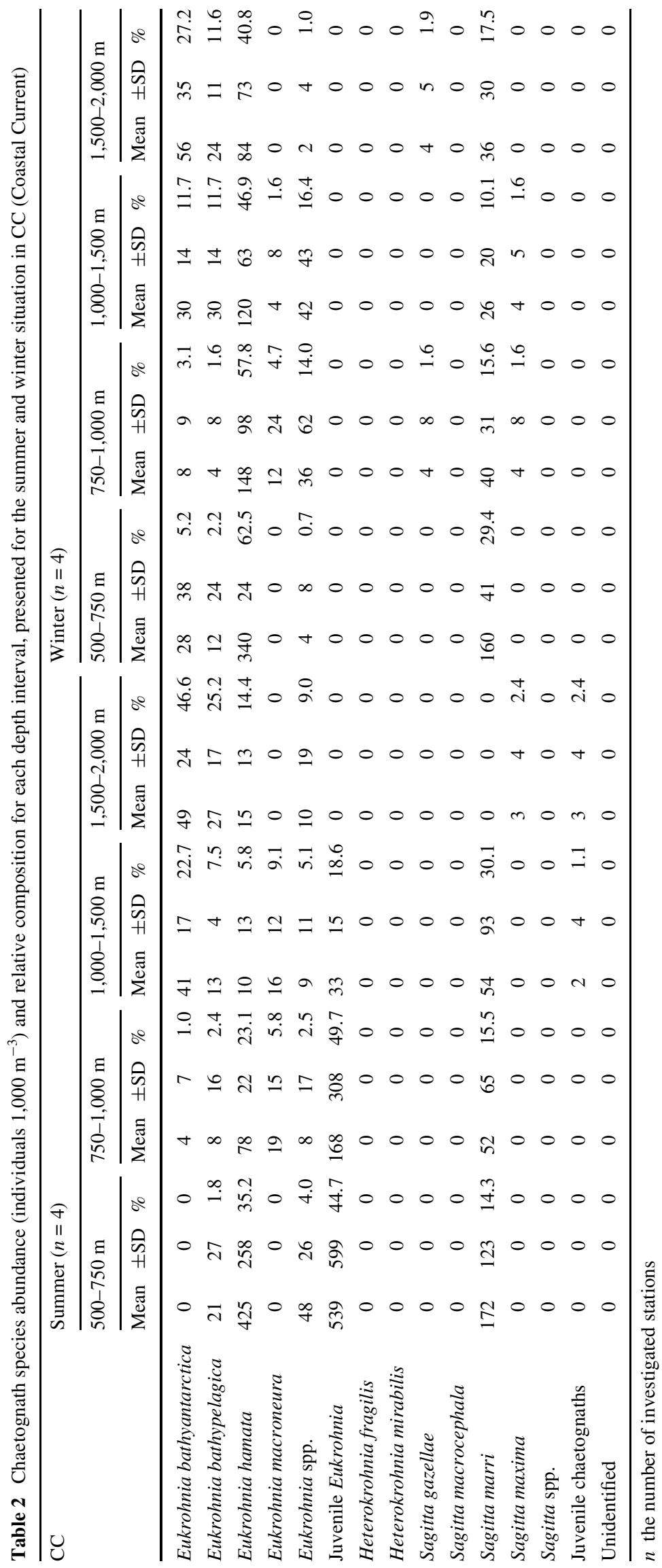




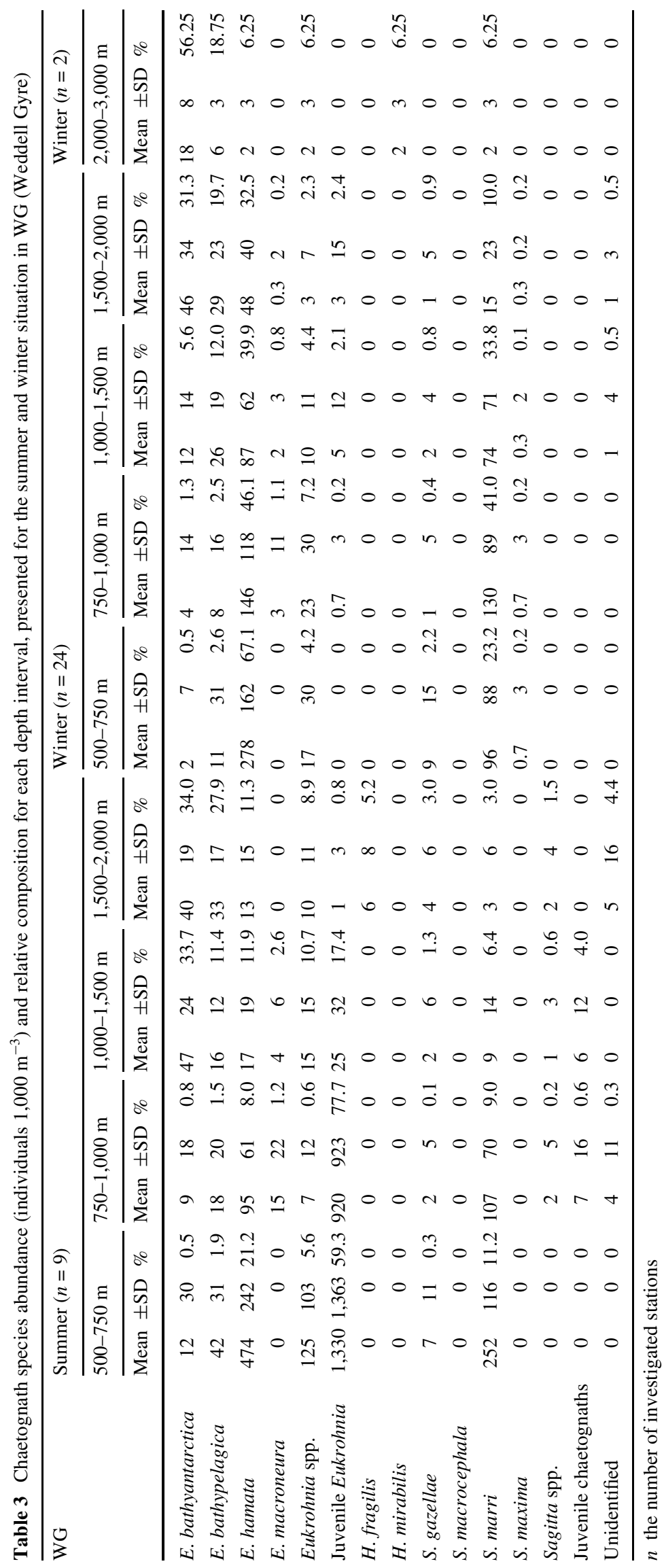


Table 4 Chaetognath species abundance (individuals $1,000 \mathrm{~m}^{-3}$ ) and relative composition for each depth interval, presented for the summer and winter situation in PFZ (Polar Frontal Zone)

\begin{tabular}{|c|c|c|c|c|c|c|c|c|c|c|c|c|}
\hline \multirow[t]{3}{*}{ PFZ } & \multicolumn{12}{|c|}{ Summer $(n=2)$} \\
\hline & \multicolumn{3}{|c|}{$500-750 \mathrm{~m}$} & \multicolumn{3}{|c|}{$750-1,000 \mathrm{~m}$} & \multicolumn{3}{|c|}{$1,000-1,500 \mathrm{~m}$} & \multicolumn{3}{|c|}{$1,500-2,000 \mathrm{~m}$} \\
\hline & Mean & $\pm \mathrm{SD}$ & $\%$ & Mean & $\pm \mathrm{SD}$ & $\%$ & Mean & $\pm \mathrm{SD}$ & $\%$ & Mean & $\pm \mathrm{SD}$ & $\%$ \\
\hline Eukrohnia bathyantarctica & 0 & 0 & 0 & 32 & 22 & 8.2 & 16 & 11 & 9.1 & 48 & 35 & 35.7 \\
\hline Eukrohnia bathypelagica & 47 & 20 & 16.3 & 40 & 34 & 10.2 & 89 & 11 & 50.0 & 32 & 22 & 23.4 \\
\hline Eukrohnia hamata & 147 & 92 & 51.4 & 79 & 22 & 20.4 & 32 & 0 & 18.2 & 16 & 0 & 11.8 \\
\hline Eukrohnia macroneura & 0 & 0 & 0 & 8 & 11 & 2.0 & 28 & 6 & 15.9 & 0 & 0 & 0 \\
\hline Eukrohnia spp. & 15 & 21 & 5.3 & 32 & 0 & 8.2 & 0 & 0 & 0 & 4 & 6 & 2.9 \\
\hline Juvenile Eukrohnia & 23 & 32 & 8.0 & 143 & 202 & 36.8 & 0 & 0 & 0 & 24 & 33 & 17.4 \\
\hline Heterokrohnia fragilis & 0 & 0 & 0 & 0 & 0 & 0 & 0 & 0 & 0 & 0 & 0 & 0 \\
\hline Heterokrohnia mirabilis & 0 & 0 & 0 & 0 & 0 & 0 & 0 & 0 & 0 & 0 & 0 & 0 \\
\hline Sagitta gazellae & 0 & 0 & 0 & 0 & 0 & 0 & 0 & 0 & 0 & 0 & 0 & 0 \\
\hline Sagitta macrocephala & 0 & 0 & 0 & 8 & 11 & 2.0 & 0 & 0 & 0 & 4 & 6 & 2.9 \\
\hline Sagitta marri & 46 & 42 & 16.1 & 32 & 22 & 8.2 & 4 & 6 & 2.2 & 0 & 0 & 0 \\
\hline Sagitta maxima & 8 & 12 & 2.9 & 8 & 11 & 2.0 & 8 & 11 & 4.6 & 4 & 6 & 2.9 \\
\hline Sagitta spp. & 0 & 0 & 0 & 8 & 11 & 2.0 & 0 & 0 & 0 & 0 & 0 & 0 \\
\hline Juvenile chaetognaths & 0 & 0 & 0 & 0 & 0 & 0 & 0 & 0 & 0 & 0 & 0 & 0 \\
\hline Unidentified & 0 & 0 & 0 & 0 & 0 & 0 & 0 & 0 & 0 & 4 & 6 & 3.0 \\
\hline
\end{tabular}

$n$ the number of investigated stations

Regarding water depth, highest abundances were encountered between 500 and 1,000 $\mathrm{m}$ in winter (Figs. 2a, 3a, 4a), attaining values up to 1,248 ind. $1,000 \mathrm{~m}^{-3}(500-750 \mathrm{~m}$, $64^{\circ} \mathrm{S} 0^{\circ} \mathrm{E}$, Fig. 3a), and between 500 to $750 \mathrm{~m}$ in summer (Figs. 2b, 3b, 4b), with a maximum of 1,470 ind. $1,000 \mathrm{~m}^{-3}$ $\left(63^{\circ} \mathrm{S} 3^{\circ} \mathrm{E}\right.$, Fig. $\left.4 \mathrm{~b}\right)$. Eukrohnia juveniles did rarely occur deeper than $1,500 \mathrm{~m}$ and distinctly preferred the 500 $1,000 \mathrm{~m}$ depth range in summer (Tables 2, 3, 4).

\section{Chaetognath species composition}

The cluster analysis of the 9 species $\times 170$ samples matrix (we excluded Heterokrohnia mirabilis, because it occurred in one of the two exceptional samples collected below $2,000 \mathrm{~m}$ only) produced a rather consistent sample grouping pattern, irrespective of the linkage method applied. Species composition was significantly affected by water depth $\left(P<0.001, \chi^{2}=144.78\right)$, season $\left(P<0.001, \chi^{2}=45.65\right)$ and water mass $\left(P=0.001, \chi^{2}=32.98\right.$; effect likelihood ratio test of the nominal logistic regression). The effect of water depth was mainly related to $E$. bathyantarctica and $E$. bathypelagica which dominated the deeper community but were almost absent in the upper layers, and to E. hamata that showed the opposite pattern (Tables 2, 3, 4). The seasonal effect was related to the less frequent species. E. bathyantarctica, E. bathypelagica, E. macroneura and H. fragilis were more frequent in summer, whereas S. gazellae was more frequent in winter. The water mass effect was most likely caused by the (non-) occurrence of species in just one water mass, such as Sagitta macrocephala and $H$. fragilis that occurred exclusively in the PFZ and the WG, respectively.

\section{Chaetognath abundance}

ANOVA of abundance data at the genus and the species level indicated that water mass had barely any effect, only the abundance of E. bathypelagica was significantly higher in Polar Frontal Zone (PFZ) than in Weddell Gyre (WG) and Coastal Current (CC, Table 5). The same holds true for the interaction of water mass and depth. Here, we found a significant effect on all species pooled (class Sagittoidea), where abundance decreased with depth within the WG and CC, and in the genus Eukrohnia, where it decreased only within the WG.

Significant seasonal differences were detected in the genera Eukrohnia and Sagitta (Table 5). Sagitta was more abundant in winter than in summer and Eukrohnia vice versa. Within the genus Sagitta, S. marri was 8 times more abundant in the $1,000-1,500 \mathrm{~m}$ stratum in winter (74 ind. $1,000 \mathrm{~m}^{-3}$ in WG, Table 3) than in summer. The higher abundance of Eukrohnia in summer, however, can be attributed to the high number of juveniles, as the dominant E. hamata was again significantly more abundant in winter.

Depth had the most distinct effect on chaetognath abundance. E. hamata, the dominant species, was significantly more abundant in the $500-750 \mathrm{~m}$ depth range than at 
Fig. 1 Geographical distribution and mean abundance of chaetognaths along the three sampling transects during winter (a) and summer (b) without juveniles. The juveniles from the summer expedition are presented separately (c). PFZ Polar Frontal Zone, $W G$ Weddell Gyre, $C C$ Coastal Current. Stations at and south of $68^{\circ} \mathrm{S}$ are considered within the $\mathrm{CC}$ (horizontal line)
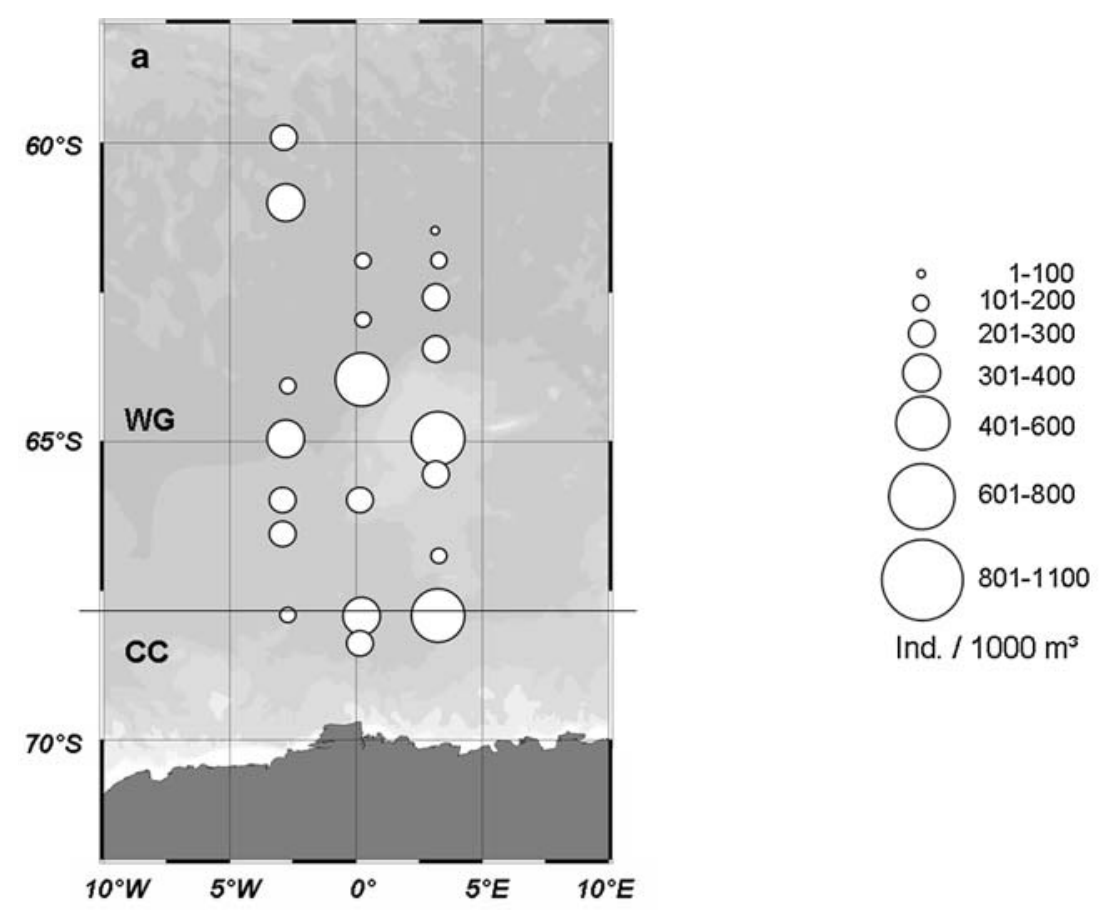

Ind. $/ 1000 \mathrm{~m}^{3}$
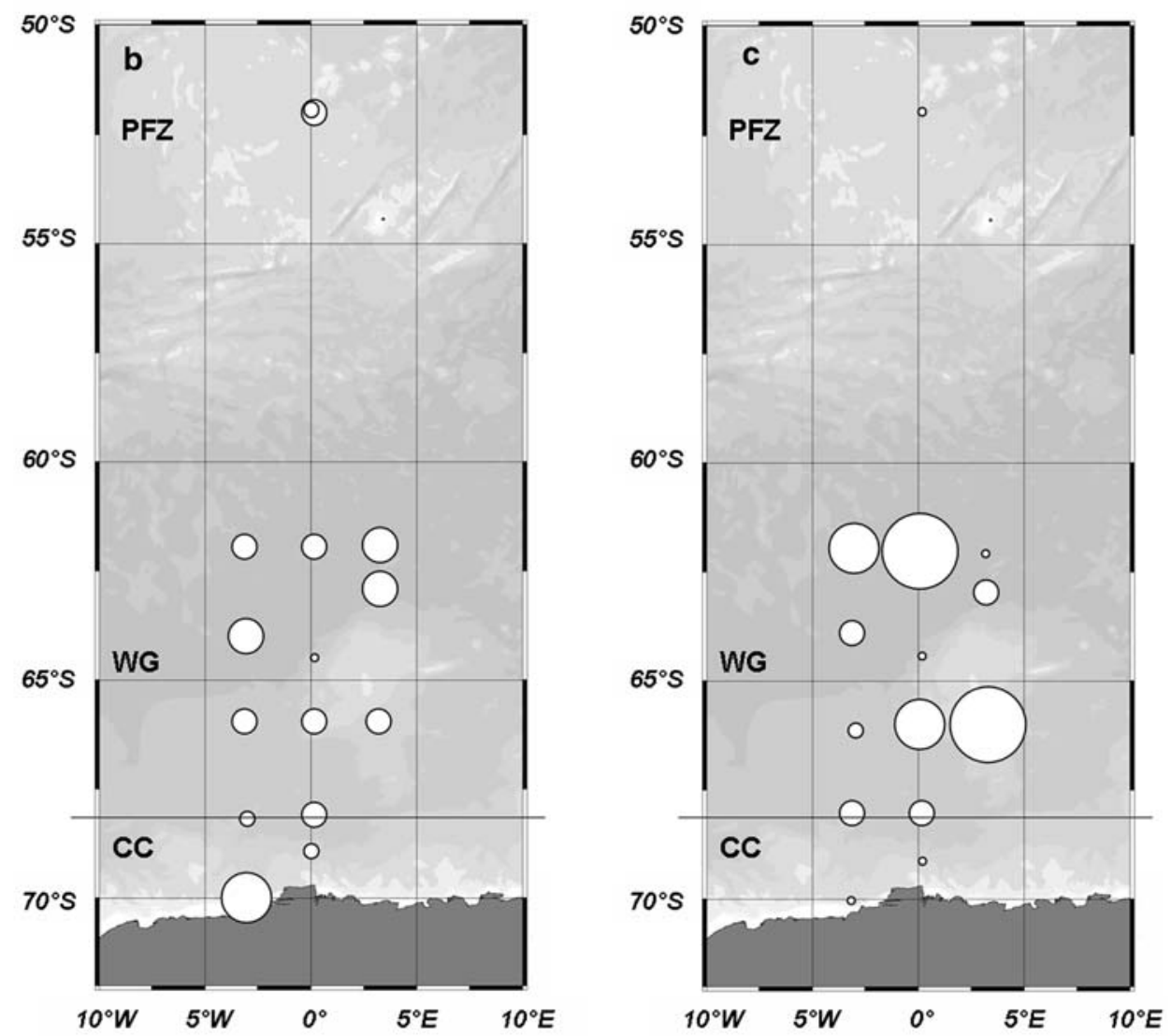

greater depths (Table 5), attaining maximum summer abundances of 425 and 474 ind. $1,000 \mathrm{~m}^{-3}$ in the CC and WG, respectively. Sagitta marri, which was second in abundance, preferred a wider depth range, 500 and
$1,000 \mathrm{~m}$, with a maximum of 252 ind. $1,000 \mathrm{~m}^{-3}$ in the WG in summer (500-750 m, Table 3). Eukrohnia bathypelagica and E. bathyantarctica showed the opposite abundance pattern, as they preferred layers below $1,000 \mathrm{~m}$ 
Fig. 2 Vertical distribution and abundance of chaetognaths (without juveniles) along the $3^{\circ} \mathrm{W}$ transect during winter (a) and summer (b). $W G$ Weddell Gyre, $C C$ Coastal Current. Stations at and south of $68^{\circ} \mathrm{S}$ are considered within the $\mathrm{CC}$ (vertical line)

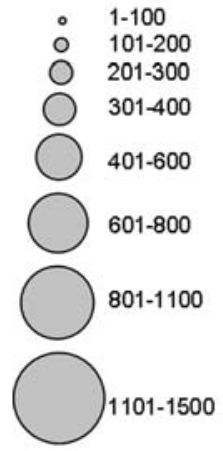

Ind. / $1000 \mathrm{~m}^{3}$
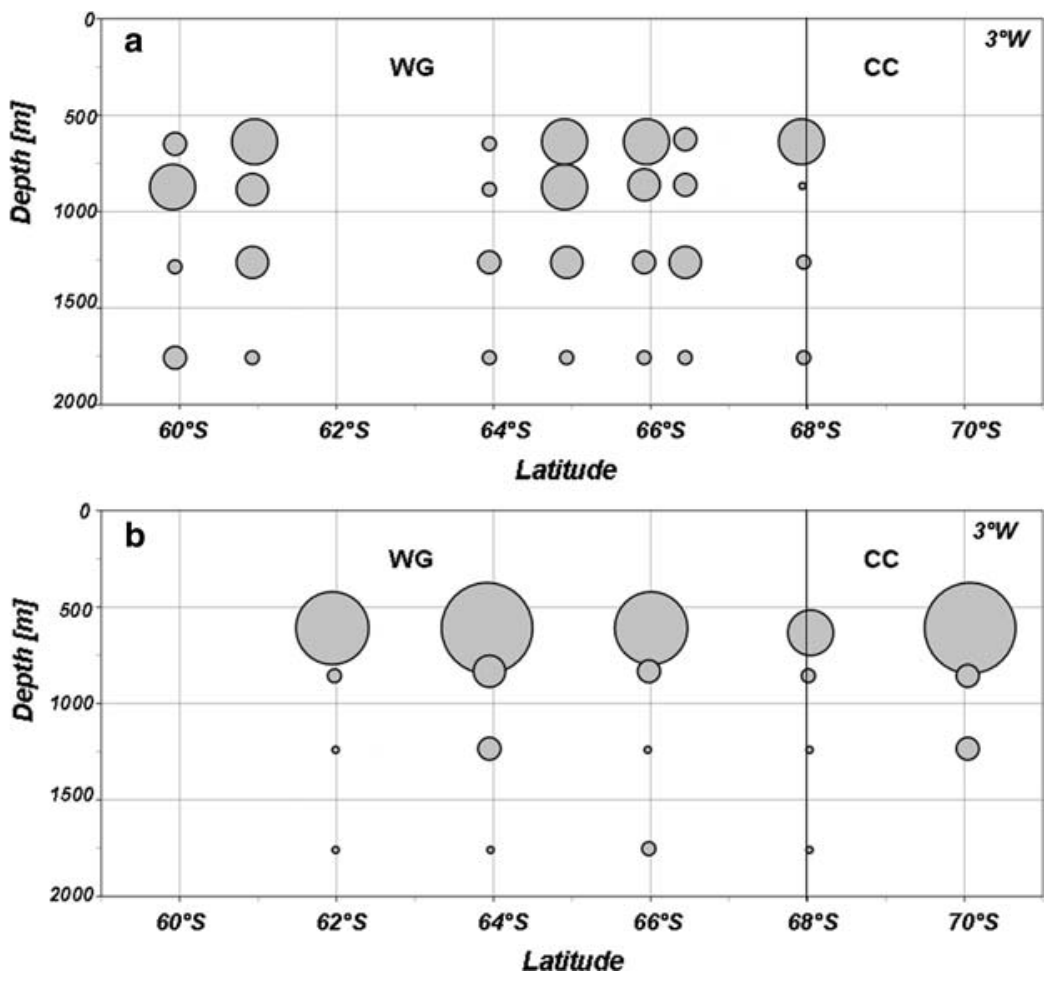

Fig. 3 Vertical distribution and abundance of chaetognaths (without juveniles) along the prime meridian during winter (a) and summer (b). $W G$ Weddell Gyre, $C C$ Coastal Current. Stations at and south of $68^{\circ} \mathrm{S}$ are considered within the $\mathrm{CC}$ (vertical line)

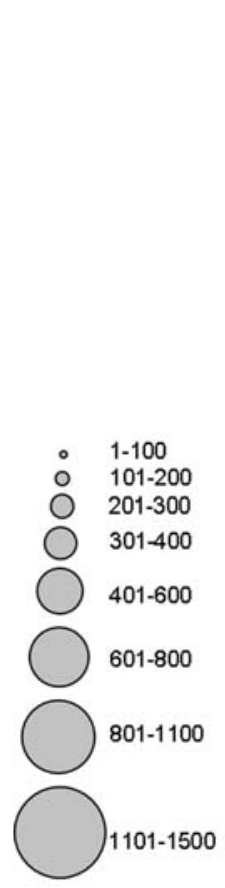

Ind. / $1000 \mathrm{~m}^{3}$
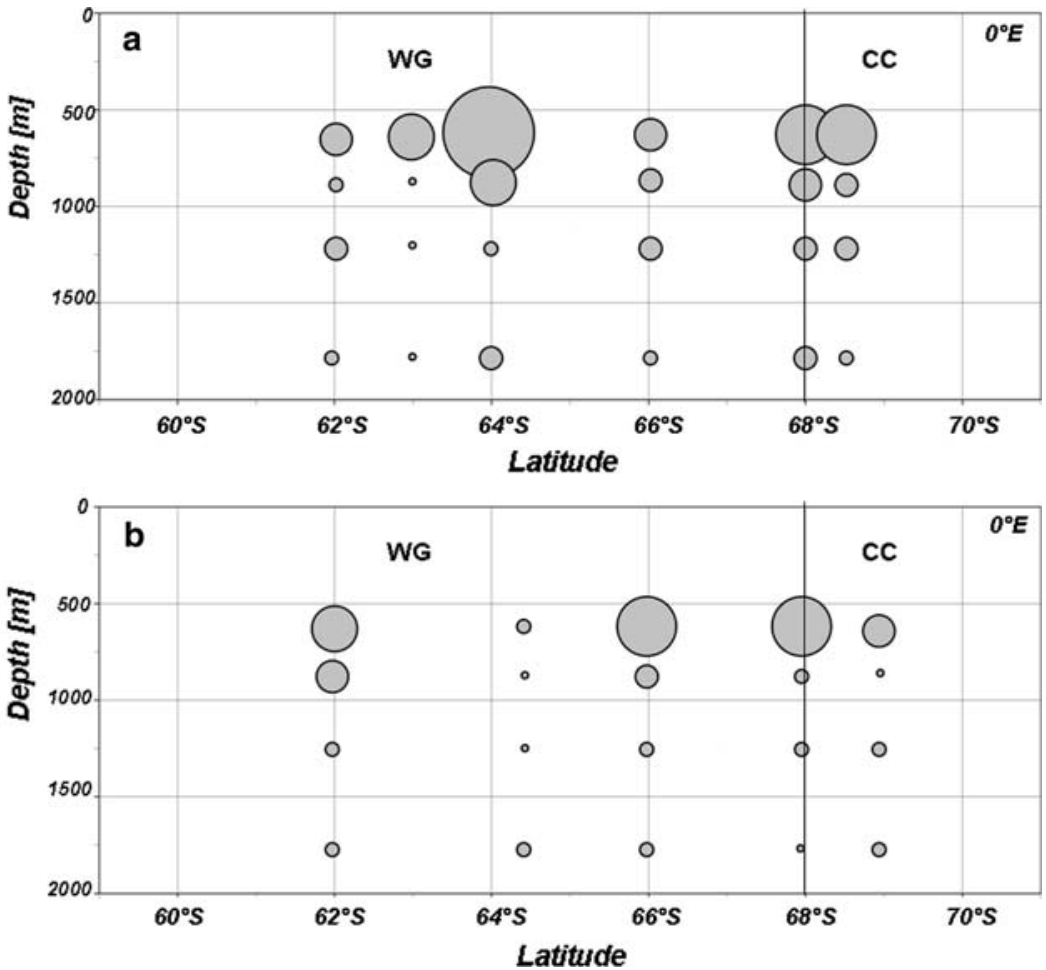

(Table 5). They reached highest numbers of 89 ind. $1,000 \mathrm{~m}^{-3}$ (summer, PFZ, 1,000-1,500 $\mathrm{m}$, Table 4) and 56 ind. 1,000 $\mathrm{m}^{-3}$ (winter, CC, 1,500-2,000 m, Table 2), respectively. Eukrohnia macroneura differed from all other species, as it was most abundant between 750 and $1,500 \mathrm{~m}$ depth (maximum of 28 ind. $1,000 \mathrm{~m}^{-3}$, summer, PFZ,
Table 4). Although juveniles of the genus Eukrohnia could not be subjected to sound statistical analyses, their centre of abundance was observed between 500 and $1,000 \mathrm{~m}$, with values up to 1,330 ind. $1,000 \mathrm{~m}^{-3}$ in the WG $(500-750 \mathrm{~m}$, Table 3 ), then representing $59.3 \%$ of total chaetognath abundance. 
Fig. 4 Vertical distribution and abundance of chaetognaths (without juveniles) along the $3^{\circ} \mathrm{E}$ transect during winter (a) and summer (b). $W G$ Weddell Gyre, $C C$ Coastal Current. Stations at and south of $68^{\circ} \mathrm{S}$ are considered within the $\mathrm{CC}$ (vertical line)

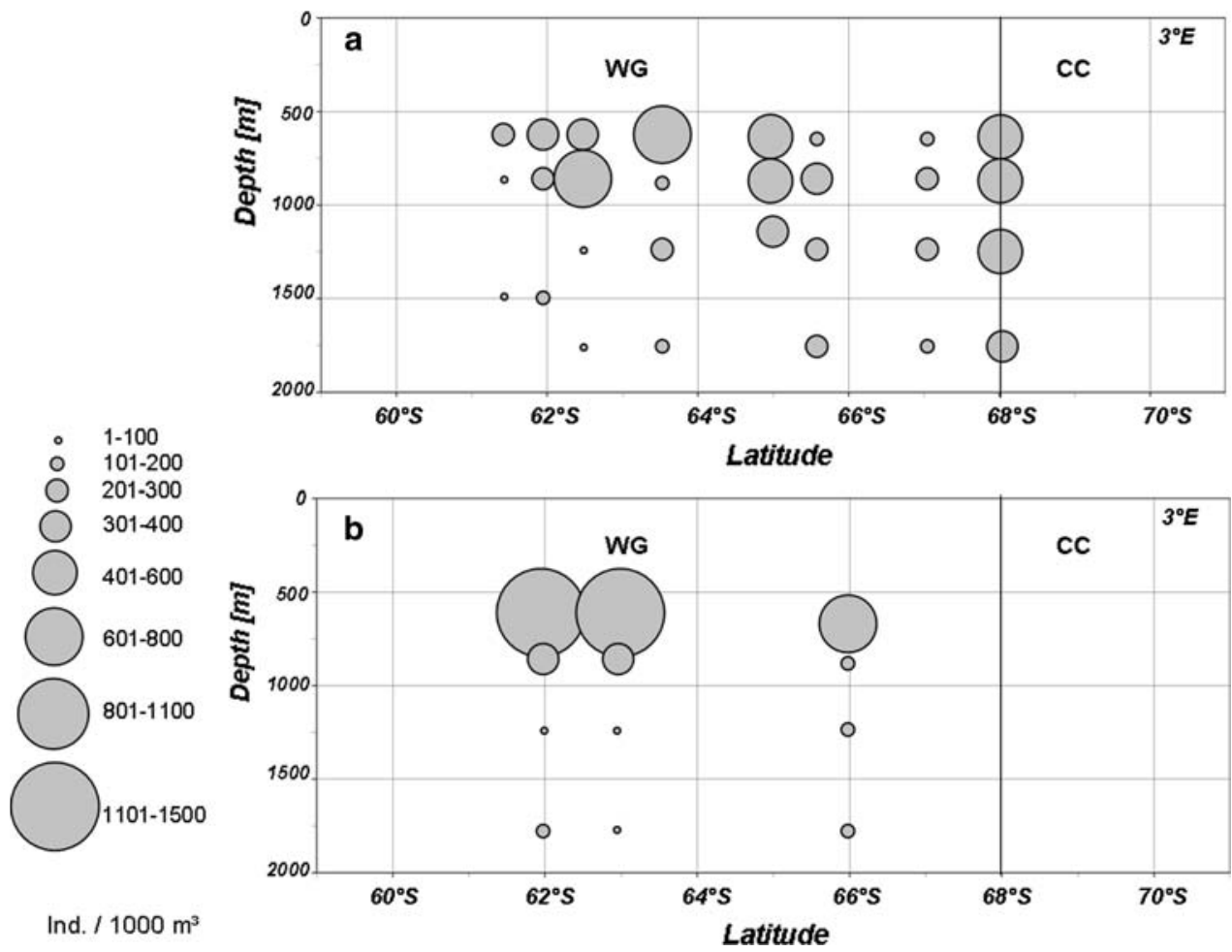

In species that showed decreasing abundance with depth (E. hamata, S. marri), this vertical gradient became significantly more distinct in summer, as indicated by the season $\times$ depth interaction term of the ANOVA (Table 5). In contrast, E. bathypelagica exhibited a more distinct depth gradient in winter, with a clear preference for the 1,000-2,000 m layer which, however, was caused mainly by a decrease in abundance in shallower layers from summer to winter.

In Sagitta gazellae we could not detect any effects of water mass, season or depth. All other species were too rare for reliable analysis. S. macrocephala was only captured in summer in the PFZ (8 ind. $1,000 \mathrm{~m}^{-3}$ in $750-1,000 \mathrm{~m}$, Table 4). S. maxima was primarily found in the PFZ as well, where this species was encountered between 500 and $1,500 \mathrm{~m}$ in summer ( 8 ind. $1,000 \mathrm{~m}^{-3}$, Table 4). Two species of Heterokrohnia were found below $1,500 \mathrm{~m}$ in the WG (Table 3). A total number of 7 individuals of $H$. fragilis (7-10 mm length) were caught in summer, H. mirabilis occurred exclusively between 2,000 and 3,000 $\mathrm{m}$ in winter and with 2 ind. $1,000 \mathrm{~m}^{-3}(6.3 \%)$ was even rarer than $H$. fragilis. Only one $H$. mirabilis specimen of $19 \mathrm{~mm}$ length was caught in the WG.

Distribution of maturity stages in E. hamata and S. marri

ANOVA of mean maturity stage showed a significant effect of all parameters investigated (Table 5). In both species, mean maturity stage was higher in the PFZ than in the WG.
Season affected E. hamata and S. marri differently; the former species showed higher mean maturity in winter, the latter in summer. Generally, mean maturity stage increased with depth. However, in E. hamata no significant differences were detected below $750 \mathrm{~m}$. In $S$. marri mean maturity stage was significantly higher in the $1,500-2,000 \mathrm{~m}$ stratum compared to the $750-1,000 \mathrm{~m}$ stratum. The interaction of season and depth indicated that in E. hamata the vertical gradient was more distinct in winter, in $S$. marri however, in summer, as in this species depth had no effect at all in winter.

Population structure of E. hamata and S. marri

\section{Eukrohnia hamata}

Of all Eukrohnia hamata caught, 99.6\% (summer) and 99.9\% (winter) were complete and could be measured. The population of $E$. hamata consisted essentially of stages 1 and 2 individuals (Fig. 5). E. hamata had a maximum length of $29 \mathrm{~mm}$ in summer and $32 \mathrm{~mm}$ in winter, respectively (Table 6). During both seasons their length increased slightly with increasing depth, as maturity stage and body length are positively correlated (winter: $r=0.764$, $P<0.001$; summer: $r=0.813, P<0.001$ ), albeit with much overlap in length between subsequent stages (Fig. 5). Comparing both seasons the mean body length per stage did not differ significantly between seasons: stage $1: 14.6 \mathrm{~mm}$, stage 2:23.3 $\mathrm{mm}$, and stage $3: 27.7 \mathrm{~mm}$. 
Table 5 Effects of water mass WM, season and depth on chaetognath abundance and maturity stage distribution (mean maturity stage per station and depth interval)

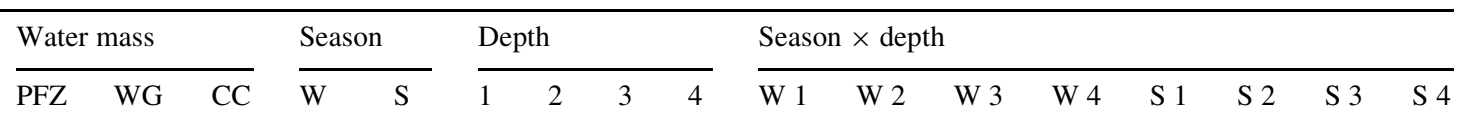

\begin{tabular}{|c|c|c|c|c|c|c|c|c|c|c|c|c|c|c|c|c|c|}
\hline \multicolumn{18}{|l|}{ Abundance } \\
\hline \multirow[t]{3}{*}{ Class Sagittoidea } & ns & & & & A & & & A & A & & & & & & & A & A \\
\hline & & & & $\mathrm{B}$ & & $\mathrm{B}$ & $\mathrm{B}$ & $\mathrm{B}$ & & $\mathrm{B}$ & $\mathrm{B}$ & & $\mathrm{B}$ & & & $\mathrm{B}$ & \\
\hline & & & & & & & & & & $\mathrm{C}$ & $\mathrm{C}$ & $\mathrm{C}$ & $\mathrm{C}$ & $\mathrm{C}$ & $\mathrm{C}$ & & \\
\hline \multirow[t]{3}{*}{ Genus Eukrohnia } & ns & & & & A & & & A & A & & & & & & & A & A \\
\hline & & & & $\mathrm{B}$ & & $\mathrm{B}$ & $\mathrm{B}$ & $\mathrm{B}$ & & $\mathrm{B}$ & $\mathrm{B}$ & & $\mathrm{B}$ & & $\mathrm{B}$ & B & \\
\hline & & & & & & & & & & $\mathrm{C}$ & $\mathrm{C}$ & $\mathrm{C}$ & $\mathrm{C}$ & $\mathrm{C}$ & $\mathrm{C}$ & & \\
\hline \multirow[t]{3}{*}{ Genus Sagitta } & ns & & & A & & & & A & A & & & A & A & & & A & A \\
\hline & & & & & B & & B & & & & $\mathrm{B}$ & $\mathrm{B}$ & $\mathrm{B}$ & & & B & \\
\hline & & & & & & $\mathrm{C}$ & & & & $\mathrm{C}$ & & & & $\mathrm{C}$ & $\mathrm{C}$ & & \\
\hline \multirow[t]{3}{*}{ E. bathyantarctica } & ns & & & & A & A & A & & & A & & & & A & A & & \\
\hline & & & & $\mathrm{B}$ & & & & $\mathrm{B}$ & $\mathrm{B}$ & & $\mathrm{B}$ & & & & & B & \\
\hline & & & & & & & & & & & & $\mathrm{C}$ & $\mathrm{C}$ & & & $\mathrm{C}$ & $\mathrm{C}$ \\
\hline \multirow[t]{2}{*}{ E. bathypelagica } & A & & & & A & A & A & & & A & A & & & $\mathrm{A}$ & A & A & A \\
\hline & & B & $\mathrm{B}$ & $\mathrm{B}$ & & & & $\mathrm{B}$ & $\mathrm{B}$ & & & $\mathrm{B}$ & $\mathrm{B}$ & & & B & \\
\hline \multirow[t]{4}{*}{ E. hamata } & ns & & & A & & & & & A & & & & A & & & & A \\
\hline & & & & & B & & & B & & & $\mathrm{B}$ & $\mathrm{B}$ & & & & B & \\
\hline & & & & & & $\mathrm{C}$ & $\mathrm{C}$ & & & $\mathrm{C}$ & $\mathrm{C}$ & & & & & $\mathrm{C}$ & \\
\hline & & & & & & & & & & & & & & $\mathrm{D}$ & $\mathrm{D}$ & & \\
\hline \multirow[t]{2}{*}{ E. macroneura } & ns & & & & A & & A & A & & & & & & & A & A & \\
\hline & & & & $\mathrm{B}$ & & $\mathrm{B}$ & & & $\mathrm{B}$ & B & B & B & $\mathrm{B}$ & $\mathrm{B}$ & & & B \\
\hline \multirow[t]{3}{*}{ S. marri } & ns & & & A & & & & A & A & & & A & A & & & A & A \\
\hline & & & & & B & & B & & & & B & B & B & & & B & \\
\hline & & & & & & $\mathrm{C}$ & & & & $\mathrm{C}$ & & & & $\mathrm{C}$ & $\mathrm{C}$ & & \\
\hline \multicolumn{18}{|l|}{ Mean stage } \\
\hline \multirow[t]{3}{*}{ E. hamata } & A & & A & A & & A & A & A & & A & A & & & & A & A & \\
\hline & & $\mathrm{B}$ & $\mathrm{B}$ & & B & & & & B & & $\mathrm{B}$ & B & $\mathrm{B}$ & $\mathrm{B}$ & B & B & \\
\hline & & & & & & & & & & & & & & $\mathrm{C}$ & & & $\mathrm{C}$ \\
\hline \multirow[t]{3}{*}{ S. marri } & A & & & & A & A & A & & & & & & & A & A & & \\
\hline & & $\mathrm{B}$ & $\mathrm{B}$ & $\mathrm{B}$ & & & $\mathrm{B}$ & & $\mathrm{B}$ & B & B & $\mathrm{B}$ & $\mathrm{B}$ & & $\mathrm{B}$ & B & B \\
\hline & & & & & & & & $\mathrm{C}$ & $\mathrm{C}$ & & & & & & & & \\
\hline
\end{tabular}

Full factorial (except WM $\times$ season) ANOVA with subsequent Tukey HSD post hoc test on differences between means $(\alpha=0.05)$, letters (A, B ...) indicate groups that differ significantly, the alphabetical order indicates decreasing abundance/mean maturity stage. The interaction term WM $\times$ depth is not shown here, because it was significant only for the class Sagittoidea where abundance decreased with depth in WG and CC, but not in PFZ, and for the genus Eukrohnia where abundance decreased with depth within WG. Sagitta gazellae is not mentioned in this table, because all tests were not significant

PFZ Polar Frontal Zone, $W G$ Weddell Gyre, $C C$ Coastal Current, $S$ summer, $W$ winter, 1: 2,000-1,500 m, 2: 1,500-1,000 m, 3: 1,000-750 m, 4: $750-500 \mathrm{~m}), n s$ no significant effect

The shape of the length-frequency distribution differed significantly between summer and winter (KolmogorowSmirnow test, $P<0.005)$. Apparently there was a higher proportion of large animals $(>20 \mathrm{~mm})$ present in winter. This coincides with a significantly higher mean maturity stage in winter (see above). Including the unidentified Eukrohnia individuals would slightly increase the stage 1 individuals (especially below $10 \mathrm{~mm}$ length), but not significantly change the size-frequency structure (KolmogorowSmirnow test, $P>0.1$ ). 
Fig. 5 Length-frequency and corresponding maturity stage distribution of Eukrohnia hamata in winter and summer. $n$ the number of investigated individuals
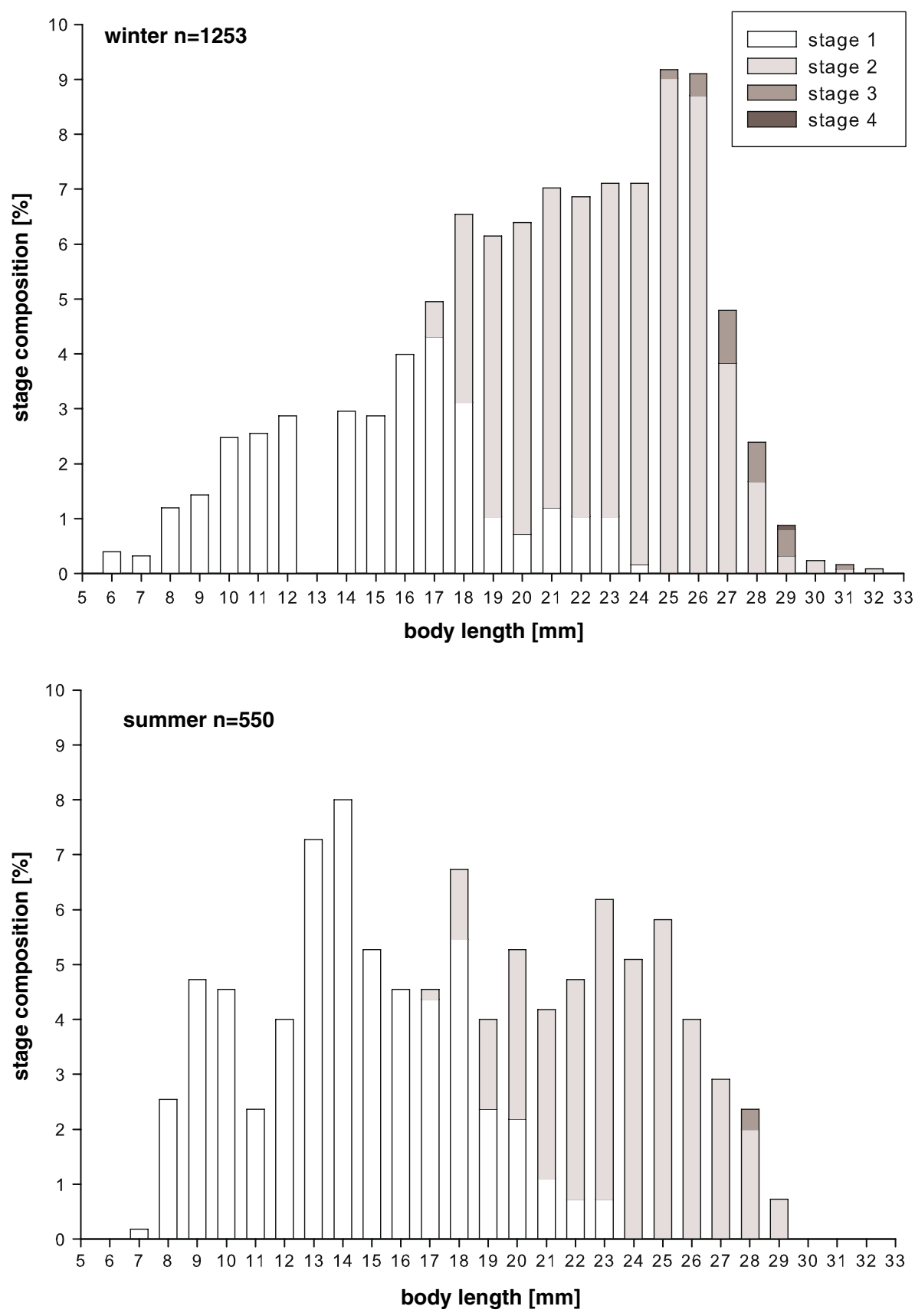

\section{Sagitta marri}

All specimens of Sagitta marri could be measured in summer, during winter the measuring success rate was $93.3 \%$. This population was dominated by maturity stages 1 and 2 (Fig. 6). Maximum body length was $27 \mathrm{~mm}$ in summer and $28 \mathrm{~mm}$ in winter, respectively (Table 7). The stage-specific mean lengths differed seasonally only between stage 1 specimens. In the 500-750 m layer $S$. marri had, e.g. a mean length of $6.8 \mathrm{~mm}$ in summer compared to $9.4 \mathrm{~mm}$ in winter. Maturity stage and length were positively correlated in this species, too (winter: $r=0.636, P<0.001$; summer: $r=0.801, P<0.001)$.

The population size-frequency structure (Fig. 6) did not differ significantly between winter and summer (Kolmogorow-Smirnow test, $P>0.1$ ). As a result of longer specimens (see above), the structure for the winter situation was shifted towards greater lengths with highest values between 8 and $11 \mathrm{~mm}$ body length dominated by stage 2 individuals. Highest values in summer were shown at 6 and $7 \mathrm{~mm}$ body length represented by stage 1 individuals. 
Table 6 Length-frequency distribution for Eukrohnia hamata in the different depth intervals for winter and summer

\begin{tabular}{|c|c|c|c|c|c|c|c|c|c|c|c|c|c|c|c|c|c|c|c|c|c|c|c|c|c|c|c|c|}
\hline \multirow[t]{2}{*}{ Depth (m) } & \multirow[t]{2}{*}{$n$} & \multicolumn{27}{|c|}{ Length (mm) } \\
\hline & & 6 & 7 & 8 & 9 & 10 & 11 & 12 & 13 & 14 & 15 & 16 & 17 & 18 & 19 & 20 & 21 & 22 & 23 & 24 & 25 & 26 & 27 & 28 & 29 & 30 & 31 & 32 \\
\hline \multicolumn{29}{|l|}{ Winter } \\
\hline $500-750$ & 490 & 5 & 4 & 5 & 8 & 14 & 11 & 15 & & 14 & 14 & 24 & 28 & 44 & 32 & 42 & 38 & 38 & 32 & 23 & 35 & 36 & 17 & 8 & 2 & & 1 & \\
\hline $750-1,000$ & 257 & & & 7 & 7 & 8 & 8 & 11 & & 4 & 7 & 9 & 14 & 9 & 15 & 13 & 20 & 18 & 23 & 18 & 26 & 24 & 11 & 4 & & & & 1 \\
\hline $1,000-1,500$ & 335 & & & 2 & 2 & 9 & 10 & 6 & & 13 & 11 & 12 & 13 & 19 & 14 & 14 & 22 & 17 & 26 & 37 & 37 & 35 & 21 & 9 & 4 & 2 & & \\
\hline $1,500-2,000$ & 171 & & & 1 & 1 & & 3 & 4 & & 6 & 4 & 5 & 7 & 10 & 16 & 11 & 8 & 13 & 8 & 11 & 17 & 19 & 11 & 9 & 5 & 1 & 1 & \\
\hline \multicolumn{29}{|l|}{ Summer } \\
\hline $500-750$ & 410 & & 1 & 14 & 24 & 25 & 9 & 20 & 36 & 38 & 24 & 24 & 21 & 31 & 15 & 24 & 19 & 17 & 24 & 19 & 10 & 9 & 5 & 1 & & & & \\
\hline $750-1,000$ & 83 & & & & & & 3 & & 3 & 3 & 3 & & & 4 & 6 & 3 & 3 & 7 & 8 & 7 & 14 & 9 & 3 & 6 & 1 & & & \\
\hline $1,000-1,500$ & 32 & & & & 1 & & 1 & 1 & 1 & & 1 & & 1 & 1 & & 1 & & 1 & 1 & 1 & 5 & 4 & 6 & 5 & 1 & & & \\
\hline $1,500-2,000$ & 25 & & & & 1 & & & 1 & & 3 & 1 & 1 & 3 & 1 & 1 & 1 & 1 & 1 & 1 & 1 & 3 & & 2 & 1 & 2 & & & \\
\hline
\end{tabular}

$n$ the number of investigated individuals

\section{Discussion}

Of the ten species found during this investigation, $E$. hamata, $S$. gazellae, $S$. marri and $S$. maxima were most frequently recorded in the past 50 years of Antarctic research (David 1958a; Alvariño 1969; Dinofrio 1973; Alvariño et al. 1983a, b; Hagen 1985; Johnson and Terazaki 2004). Different nets of varying and rather coarse mesh sizes were used in previous studies compared to our multinet with 100- $\mu \mathrm{m}$ mesh size. Thus, abundance data are difficult to compare, as we have caught smaller (younger) animals with higher efficiency, but larger chaetognaths (e.g. S. gazellae, Hagen 1985) may be underrepresented to some extend due to active escape reactions.

Parameters influencing chaetognath abundance and species composition

\section{Water mass}

Spatial variability of chaetognath abundance is enormous (Fig. 1), even on small scales, as observed during all hauls at the station located at the ice camp (WG) within 5 days and $32 \mathrm{~nm}$ total drift distance (start to end distance, $7 \mathrm{~nm}$ ). This patchiness, that is typical for zooplankton, might have obscured to a large extent differences in chaetognath abundance and composition between the three different water masses PFZ, WG and CC.

The sole finding of Sagitta macrocephala in the PFZ supports previous reports, as this species was described to be more frequent in the deep mesopelagic layers of the Subantarctic than in those of the Antarctic waters (David 1958a, 1965). We found just one significant effect of water mass: Eukrohnia bathypelagica was more abundant in the PFZ than in the other two water masses, particularly below $750 \mathrm{~m}$ (Tables 2, 3, 4). At this depth a tongue of warm (about $2^{\circ} \mathrm{C}$ ) and saline (>34.7) water stretches from Subantarctic into polar regions (Schröder and Fahrbach 1999). One should keep in mind that our stations were situated at the southernmost edge of the PFZ or Antarctic Convergence. Thus, our data might not have caught the full impact of the particular PFZ hydrodynamics on chaetognath distribution. This might also explain to some extent that we did not see higher abundance of $E$. hamata in PFZ waters. E. hamata, a cosmopolitan species (Alvariño 1969), is considered to be the most abundant species in Subantarctic and Antarctic waters, showing maximum abundance in the vicinity of the Antarctic convergence where higher densities have been reported even deeper in the water column (David 1958a). In the top $500 \mathrm{~m} \mathrm{E}$. hamata is known to reach maximum concentrations (David 1958a, 1965; Johnson and Terazaki 2004); hence, generally higher densities of $E$. hamata may occur around the Antarctic Convergence in the epipelagic realm. In general, the upper layer of this water body reveals higher plankton concentrations than adjacent areas (Voronina 1968). Between $49^{\circ}$ and $50^{\circ} \mathrm{S}$, highest downward velocity is observed at $20^{\circ} \mathrm{E}$ which results in an increased zooplankton abundance especially in the upper $100 \mathrm{~m}$ (Voronina 1968). In the meso- and bathypelagial of the Antarctic Convergence, however, these differences in zooplankton density are probably not detectable any more.

\section{Water depth}

Depth was found to be the major determinant of chaetognath abundance and distribution on all taxonomic levels.

Eukrohnia hamata was the dominant species in terms of abundance, especially between 500 and 1,000 m. It showed a significant decrease in abundance with depth, a pattern already found in previous studies (e.g. Alvariño et al. 1983a, b). E. bathypelagica and E. bathyantarctica coexist 
Fig. 6 Length-frequency and corresponding maturity stage distribution of Sagitta marri in winter and summer. $n$ the number of investigated individuals
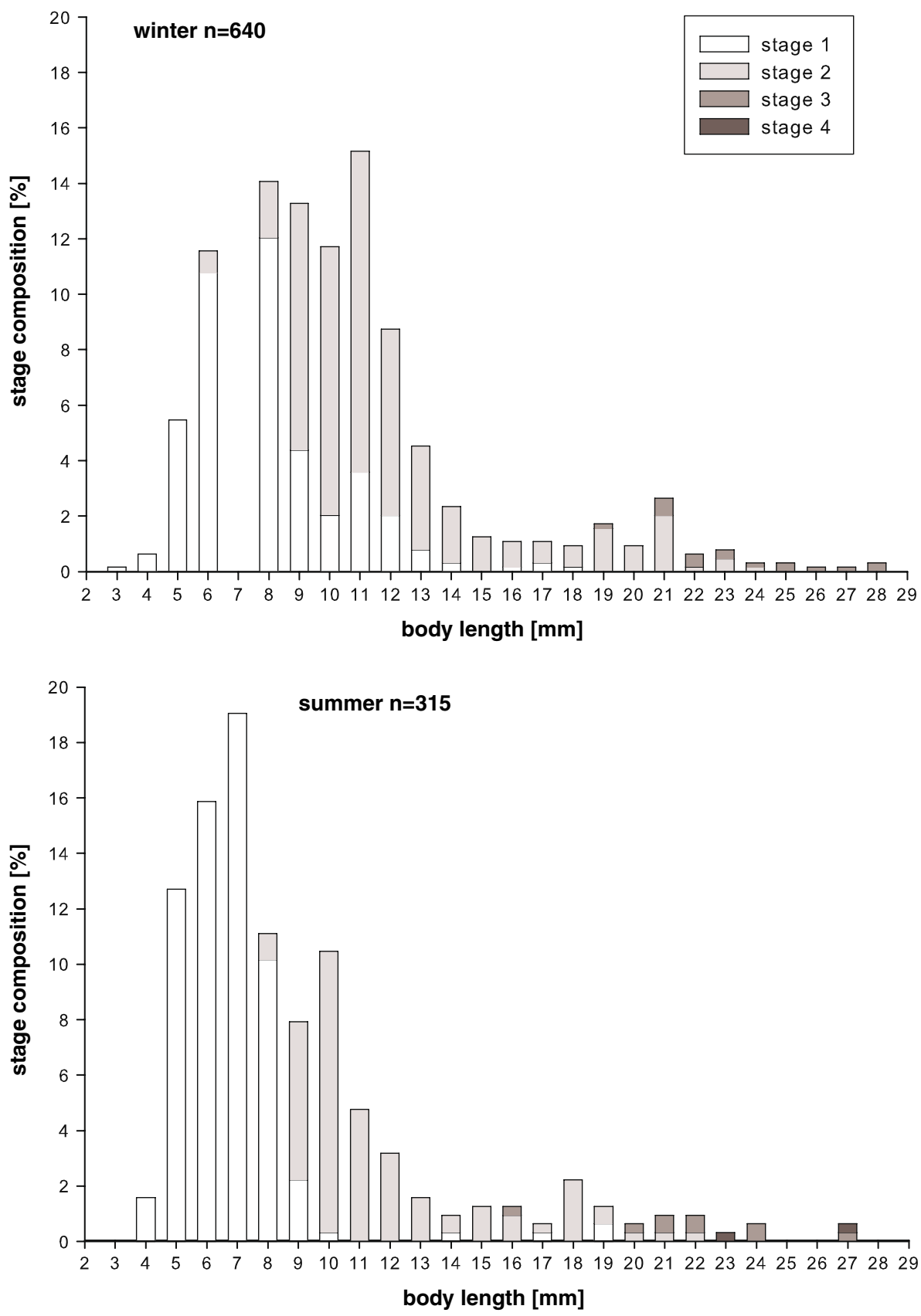

with, and partially displace, E. hamata in the deep mesoand bathypelagic oceanic strata. Whereas E. bathypelagica, a species with a worldwide distribution (e.g. Rottmann 1978, Gulf of Thailand; Terazaki 1996, Equatorial Pacific), inhabits the layers below $500 \mathrm{~m}$, E. bathyantarctica occurs mainly below $1,000 \mathrm{~m}$ in Antarctic waters.

Eukrohnia bathypelagica dominated the 1,000-2,000 m depth range and reached average numbers of up to 33 ind. $1,000 \mathrm{~m}^{-3}$ in summer in the WG $(1,500-2,000 \mathrm{~m})$ and 89 ind. $1,000 \mathrm{~m}^{-3}$ in the PFZ (1,000-1,500 m). So far, only Alvariño et al. (1983a, b) provided detailed information on the geographical and bathymetric distribution of
E. bathypelagica in the Southern Ocean. In summer, they observed low densities of $E$. bathypelagica ( $\leq 10$ ind. $1,000 \mathrm{~m}^{-3}$ ) in the meso- and bathypelagial of the Scotia Sea, Weddell Sea and the Drake Passage, which is three times less than we observed in average. The winter data given by Alvariño et al. (1983a) excluded the Weddell Sea, but data for the South Pacific showed largest abundances of up to 1,000 ind. $1,000 \mathrm{~m}^{-3}$ below $1,000 \mathrm{~m}$ north of $60^{\circ} \mathrm{S}$. To the south this species always occurred with less than 100 , in some areas dropped even below 10 ind. $1,000 \mathrm{~m}^{-3}$ in the meso- and bathypelagic zone. We note that Alvariño et al. (1983a) included the 200-500 $\mathrm{m}$ range in 
Table 7 Length-frequency distribution for Sagitta marri in the different depth intervals for winter and summer

\begin{tabular}{|c|c|c|c|c|c|c|c|c|c|c|c|c|c|c|c|c|c|c|c|c|c|c|c|c|c|c|c|}
\hline \multirow[t]{2}{*}{ Depth (m) } & \multirow[t]{2}{*}{$n$} & \multicolumn{26}{|c|}{ Length (mm) } \\
\hline & & 3 & 4 & 5 & 6 & 7 & 8 & 9 & 10 & 11 & 12 & 13 & 14 & 15 & 16 & 17 & 18 & 19 & 20 & 21 & 22 & 23 & 24 & 25 & 26 & 27 & 28 \\
\hline \multicolumn{28}{|l|}{ Winter } \\
\hline $500-750$ & 167 & 1 & 1 & 4 & 8 & & 12 & 24 & 16 & 34 & 20 & 12 & 1 & 5 & 5 & 3 & 2 & 6 & 2 & 6 & 1 & 3 & & 1 & & & \\
\hline $750-1,000$ & 183 & & 1 & 17 & 15 & & 29 & 29 & 18 & 30 & 17 & 8 & 1 & 1 & 1 & 1 & 1 & 2 & 2 & 6 & 2 & & 2 & & & & \\
\hline $1,000-1,500$ & 232 & & 2 & 12 & 46 & & 40 & 27 & 32 & 24 & 16 & 7 & 11 & & 1 & & 1 & 2 & 1 & 3 & 1 & 1 & & 1 & 1 & 1 & 2 \\
\hline $1,500-2,000$ & 58 & & & 2 & 5 & & 9 & 5 & 9 & 9 & 3 & 2 & 2 & 2 & & 3 & 2 & 1 & 1 & 2 & & 1 & & & & & \\
\hline \multicolumn{28}{|l|}{ Summer } \\
\hline $500-750$ & 201 & & 5 & 29 & 31 & 34 & 23 & 17 & 22 & 9 & 5 & 4 & 2 & 3 & 4 & 2 & 3 & 4 & 1 & 2 & 1 & & & & & & \\
\hline $750-1,000$ & 75 & & & 9 & 15 & 18 & 7 & 6 & 6 & 5 & 2 & & 1 & & & & 1 & & 1 & 1 & 1 & 1 & 1 & & & & \\
\hline $1,000-1,500$ & 35 & & & 2 & 4 & 8 & 5 & 2 & 5 & 1 & 3 & 1 & & 1 & & & 1 & & & & 1 & & & & & 1 & \\
\hline $1,500-2,000$ & 4 & & & & & & & & & & & & & & & & 2 & & & & & & 1 & & & 1 & \\
\hline
\end{tabular}

$n$ the number of investigated individuals

the mesopelagic zone, thus making their and our numbers difficult to compare. Nevertheless, our observations on E. bathypelagica-wide distribution and rather similar abundance below $500 \mathrm{~m}$ in the Lazarev Sea-complement the data of Alvariño et al. (1983a).

Eukrohnia bathyantarctica was considered to be an endemic circumpolar Antarctic species first (David 1958b), but later it was found in other regions, too, e.g. in the Gulf of Mexico, the Caribbean Sea and off the Chilean coast (Fagetti 1968, 1972). Observations on this species are few, primarily due to the low sampling depths chosen during most investigations, and secondly because most sampling used large mesh sizes. Particularly winter records of this species are very rare (e.g. Alvariño et al. 1983a, b), hence the data presented here (complemented by Kruse 2009) are unique and contribute to a better understanding of this deep-living species. Our samples indicate a significant preference for deeper layers (>1,000 m, Table 5), in the CC and PFZ it was even completely absent above $750 \mathrm{~m}$ during summer (Tables 2, 3, 4). Maximum abundance of adults was $<60$ ind. $1,000 \mathrm{~m}^{-3}$, but total abundance below $1,000 \mathrm{~m}$ was distinctly higher in the $\mathrm{CC}$, as $83 \%$ of the Eukrohnia juveniles found there could be attributed to E. bathyantarctica. Both David (1964) and Alvariño et al. (1983a) reported a similar vertical distribution for E. bathyantarctica, highest numbers were found below 1,500 and $1,000 \mathrm{~m}$, respectively, particularly in summer.

The blind chaetognath Eukrohnia marcroneura was first described from the eastern Atlantic, between about $0^{\circ}$ and $18^{\circ}$ S. E. macroneura lives at greater depths than E. hamata, from which it has been evolved (Casanova 1986). Few records exist of this species (Pierrot-Bults and Nair 1991). Here, we present the first record of E. macroneura from the Antarctic Ocean that extends its geographical distribution distinctly into colder regions thus demonstrating a wider tolerance of hydrographical factors. E. macroneura preferred the depth range between 750 and 1,500 m. Its vertical distribution overlapped with the one of $E$. bathyantarctica, but it was distinctly less abundant.

Within the genus Sagitta, S. marri and S. gazellae are the only endemics from the Antarctic epi- and mesopelagic zone (Pierrot-Bults and Nair 1991). S. marri was the second most abundant chaetognath species in our study (Tables 2 , $3,4)$. It occurred preferentially between 500 and $1,000 \mathrm{~m}$ (Table 5), with a maximum of 252 ind. $1,000 \mathrm{~m}^{-3}(500$ $750 \mathrm{~m}$ ) in the WG in summer. Both Hagen (1985) and Alvariño et al. (1983a) reported similar vertical patterns with maxima within the $250-735 \mathrm{~m}$ and the $200-1,000 \mathrm{~m}$ depth range, respectively. In the mesopelagic layer, Alvariño et al. (1983a) found summer abundances of mostly up to 100 , occasionally up to 1,000 ind. $1,000 \mathrm{~m}^{-3}$. Interestingly, they observed comparable numbers at some locations in the bathypelagic realm, which, however, declined sharply towards south to numbers $<10$ ind. $1,000 \mathrm{~m}^{-3}$.

Sagitta gazellae was only found in very low numbers $\left(<10\right.$ ind. $1,000 \mathrm{~m}^{-3}$ ) over the complete depth range, but in the WG only. This species is known to have highest abundances between 50 and $100 \mathrm{~m}$ (David 1964), where it coexists with E. hamata, although, it may occur down to $3,000 \mathrm{~m}$, particularly stages of higher maturity (David 1955). Our abundance data are even below those reported by Alvariño et al. (1983a), below 10 ind. $1,000 \mathrm{~m}^{-3}$ compared to up to 100 ind. $1,000 \mathrm{~m}^{-3}$ in the mesopelagic zone of the South Atlantic, but owing to the overall low numbers it is difficult to say whether this discrepancy results from different sampling schedules/gears, or is just statistical noise. David (1958a) observed an extension of S. gazellae occurrence into deeper waters $(\mathrm{ca} .700 \mathrm{~m})$ in the region of the Antarctic Convergence which, however, we cannot confirm. 
Sagitta maxima was rarely encountered, with highest abundances $\left(<10\right.$ ind. $\left.1,000 \mathrm{~m}^{-3}\right)$ in the PFZ and showed no distinct vertical distribution pattern. As this species is seen as the Subantarctic counterpart of $S$. marri with a main distribution between 150 and $500 \mathrm{~m}$ (David 1965), our few observations are not surprising.

Heterokrohnia species are rarely caught and most of them are found in the deep bathypelagial (Pierrot-Bults and Nair 1991). These authors presumed provincialism among the more recently described abyssal bathyplanktonic species of Heterokrohnia including $H$. fragilis, $H$. longidentata and $H$. longicaudata for the Antarctic region. Our few findings of the two species $H$. fragilis and $H$. mirabilis confirm the preference of this genus for the deep bathypelagial which coincides with earlier recordings (Tchindonova 1955; David 1958a; Bieri 1959; Pierrot-Bults and Nair 1991). Moreover, a vertical segregation between $H$. fragilis (above 2,000 m) and the very rare $H$. mirabilis (below $2,000 \mathrm{~m}$ ) might exist.

\section{Season}

Seasonal differences in presence and vertical distribution of chaetognaths are linked to species life histories. These are associated with seasonal and breeding migrations (David 1965). Generally, the number of chaetognath species as well as of abundance, except within certain species (see above), decrease with increasing depth (Alvariño 1964). Highest numbers are found in the epipelagic zone, the best known part of the water column, however, is omitted from this study. This hampers the interpretation of seasonal effects to a certain extent. Our data confirm the general decline of chaetognath abundance with depth (Figs. 2, 3, 4), but indicate seasonal differences:

Chaetognaths in general and particularly E. hamata, $S$. marri and E. bathypelagica, occurred slightly deeper in the water column in winter. Furthermore, E. hamata and $S$. marri were more numerous in winter than in summer, whereas E. bathypelagica and E. bathyantarctica showed the opposite trend.

A downward vertical migration towards winter was observed in E. hamata and suggested for S. marri (David 1958a). Higher abundances at greater depth in winter were also indicated in E. hamata in the South Pacific $\left(130^{\circ} \mathrm{W}\right.$ to $90^{\circ} \mathrm{W}$, Alvariño et al. 1983a). For E. hamata, Alvariño et al. (1983a) reported high numbers during summer and fall in the epipelagic layer, whereas large numbers between 200 and $1,000 \mathrm{~m}$ depth were found in fall and winter. $S$. marri was described to occur at low densities in the epipelagic and at moderate numbers in the meso- and bathypelagic realm during winter, but the data of Alvariño et al. (1983a) give no indication of seasonal differences. Our data indicate a winterly downward migration in E. hamata and in S. marri, and a corresponding upward migration in Eukrohnia bathyantarctica. E. bathypelagica appears to accumulate in the 1,000-1,500 m layer by down as well as upward migration in winter.

The drivers of this seasonal migration are not yet clear. Johnson and Terazaki (2004) suggested that, while the chaetognath distribution in the subarctic Pacific is determined by temperature, the vertical distribution of Antarctic chaetognaths might rather be controlled by prey availability. If this would be true, chaetognaths might trace the migrating copepods to deeper layers in winter, or in case of E. bathypelagica and E. bathyantarctica, to shallower layers in summer. Further studies on the gut contents should focus on this hypothesis.

\section{Vertical segregation of developmental stages}

Besides seasonality, ontogenesis has an important influence on vertical species distribution. A vertical segregation of size classes and corresponding maturity stages of $E$. hamata has been reported by several authors for the North Pacific (Sullivan 1980; Johnson and Terazaki 2003), the Arctic (Sameoto 1987; Timofeev 1998) and the Antarctic (Kramp 1939; David 1965; Øresland 1995). While the sexually mature chaetognaths aggregate at depth where they spawn, the eggs or juveniles rise up to the surface layer. During their development and maturation they start to migrate down to greater depth again (Kramp 1939; Alvariño 1964; Sullivan 1980; Hagen 1985; Øresland 1995; Timofeev 1998). Juveniles of Eukrohnia were concentrated between 500 and $1,000 \mathrm{~m}$ in summer, from where they may ascend to surface layers during their development. The small numbers of juveniles in winter may indicate either a reproduction break or a migration closer to the surface. Stages 1 and 2 dominated over a wide depth range in the present study and showed an increasing length with greater depth during both seasons. Most of the growth may take place during the first stages of development. This strategy facilitates the escape from the prey spectrum of small sized predators and increases the own prey size spectrum simultaneously (Øresland 1995). The advanced maturity stages occurred deeper (higher mean maturity stage in E. hamata and $S$. marri) and seem to invest less in growth and more in the development of the reproductive organs (observed for $S$. gazellae by David 1955). The migration of adult specimens to greater depth might be common in chaetognaths. Alvariño (1964) hypothesised that this is a purely physical process, owing to the increasing specific weight concurrent with the maturity of the gonads. However, some species, e.g. Sagitta lyra and $S$. hexaptera, have voluminous and gelatinous inner parts in the lateral fins which compensate the increased density (Kapp 1991b). Thus, alternative or 
additional mechanisms are at work, the downward migration could, for instance, protect from large epipelagic predators.

\section{Life cycles}

The wide size range of $E$. hamata specimens encountered in winter and summer indicates an extended or even continuous period of reproduction, as presumed by Øresland (1995). Surprisingly, however, we found no stage 4 individuals in summer and just a few in winter, and no individuals carrying brood sacs (defined as stage 5). Øresland $(1990,1995)$ made the same observations in Gerlache Strait and concluded that these brood sacs are either easily damaged during sampling or extremely rare. However, Dawson (1968) and Timofeev (1998) found E. hamata with brood sacs. As we caught E. bathypelagica and E. bathyantarctica with brood sacs, too, the sampling method is unlikely to be responsible for the absence in E. hamata. Moreover, large individuals of about $30 \mathrm{~mm}$ length but still far away from maturity were caught, as reported by Kramp (1939) from Greenland waters, too. So, how did we miss the mature E. hamata? There are two possibilities: on the one hand, mature E. hamata occur below our maximum sampling depth of 2,000 m. This is the case in the Arctic Basin, where Dawson (1968) reported mature E. hamata descending deeper than $3,000 \mathrm{~m}$. On the other hand, our sampling schedule may have mis-matched the periods of high reproductive activity, or in contrast, continuous reproduction takes place on such a low level (Øresland 1990, 1995) that we did not catch mature individuals just by chance. Continuous but low breeding would explain the high number of 120-151 eggs per specimen (Arctic Ocean, Timofeev 1998) necessary to sustain the population of this species. Prospective seasonal and deep bathypelagic sampling should give an answer to this open question.

The lack of unimodality in the length-frequency distribution of $E$. hamata during both seasons indicates a rather complex life cycle. It might be longer than 1 year and include several reproductive periods. Thus, our observations seem to support the hypothesis of a 2-year life cycle (reviewed by Pearre 1991). However, the epipelagic layer was not included in the present study. Epipelagic data as presented by Hagen $(1985)$ and Øresland $(1990,1995)$ from the Antarctic Peninsula show that there are great numbers of small and young chaetognaths. Moreover, the unidentified Eukrohnia individuals were not included in the lengthfrequency distribution, which might again slightly underestimate the number of smaller stage 1 individuals.

Observations on the life cycle of $S$. marri are lacking so far. Nothing is known except that this species matures in the 750 to $1,000 \mathrm{~m}$ depth range (David 1965). Vertical segregation of maturity stages in this species was not as pronounced as in E. hamata. Stage 1 and 2 individuals inhabited almost the complete sampling range. More stage 1 individuals occurred at depth in winter and more stage 2 individuals in summer, resulting in higher mean maturity in summer than in winter. Although the mean maturity stage was highest between 1,500 and 2,000 $\mathrm{m}$ depth, this is only based on few stage 3 and 4 individuals.

From the two seasons studied it can be suggested that $S$. marri reproduces in spring or early summer and in fall. As small juveniles and large stage 3 individuals (maximum length 27 and $28 \mathrm{~mm}$, respectively) occurred during both seasons, reproduction may be continuous. However, generation time of $S$. marri cannot be inferred from our data.

\section{Conclusions}

This investigation provides detailed information on the effect of water mass, season and water depth on the geographical and vertical distribution and abundance of chaetognaths in the Lazarev Sea. Compared to other regions of the world oceans and to other zones within the Antarctic such as the surroundings of the Antarctic Peninsula, the Lazarev Sea has rarely been sampled. Winter studies and investigations of the meso- and especially bathypelagic realm are very scarce. However, our observations are in accord with the worldwide distribution pattern of chaetognaths reviewed by PierrotBults and Nair (1991). Additional extensive data are presented here on the abundance of E. bathypelagica and E. bathyantarctica, the two species dominating the bathypelagic zone. In addition to current knowledge of diversity and prevailing species, E. macroneura was found for the first time in the Antarctic Ocean. Other rare species such as Heterokrohnia fragilis were observed occasionally below $1,500 \mathrm{~m}$. A wide geographical distribution of these deep-living species can be suggested, albeit our knowledge on deepliving species is restricted by quite limited sampling from the bathypelagic in a few geographical locations. Beyond the insight in the deep water community of the Lazarev Sea, our data form the basis for further studies on the biology of chaetognaths. The observations on E. hamata and S. marri as well as on E. bathypelagica and E. bathyantarctica (Kruse 2009) indicate that most Antarctic chaetognaths reproduce over an extended period of the year, either in several pulses or even continuously throughout the year. Therefore, more effort should be concentrated on the investigation of deep mesopelagic and bathypelagic species, focusing especially on their life cycles, activity and feeding.

Acknowledgments We wish to thank the captain and the crew of the RV "Polarstern" for their support. We also thank Ruth Alheit who helped with the deployment of the multinet during ANT 23-6. Special thanks go to Helga Kapp for giving an introduction into Antarctic chaetognaths taxonomy. Helpful comments by Ruth Alheit, Helga Kapp, 
Bettina Meyer, Richard Crawford and three anonymous reviewers are highly appreciated.

\section{References}

Agresti A (2002) Categorial data analysis. Wiley-Interscience, New York, $\mathrm{p} 734$

Alvariño A (1962) Two new pacific chaetognaths. Their distribution and relationship to allied species. Bull Scripps Inst Oceanogr $8: 1-50$

Alvariño A (1964) Bathymetric distribution of chaetognaths. Pac Sci 18:64-82

Alvariño A (1969) Los Quetognatos del Atlantico. Distribucion y notas esenciales de sistematica. Trab Inst Esp Oceanogr 37:1-290

Alvariño A, Hosmer SC, Ford RF (1983a) Antarctic Chaetognatha: United States Antarctic Research Program Eltanin cruises 8-28, Part 1. Antarct Res Ser 34:129-338

Alvariño A, Verfaillie DF, Ford RF (1983b) Antarctic Chaetognatha: United States Antarctic Research Program Eltanin cruises 10-23, 25 and 27, Paper 2. Antarct Res Ser 39:69-204

Bielecka L, Zmijewska MI (1993) Chaetognatha of Drake Passage and Bransfield Strait (December 1983-January 1984, BIOMASS-SIBEX). Pol Polar Res 14:65-74

Bieri R (1959) The distribution of the planktonic Chaetognatha in the Pacific and their relationship to the water masses. Limnol Oceanogr 4:1-28

Blachowiak-Samolyk K, Bielecka L, Zmijewska MI (1995) Population structure of Chaetognatha in the Atlantic sector of the Southern Ocean. Pol Polar Res 16:163-174

Bone Q, Kapp H, Pierrot-Bults AC (1991) Introduction and relationship of the group. In: Bone Q, Kapp H, Pierrot-Bults AC (eds) The biology of chaetognaths. Oxford University Press, Oxford, pp 1-4

Casanova J-P (1986) Deux nouvelles espèces d'Eukrohnia (Chaetognathes) de l'Atlantique sud-tropical africain. Bull Mus Natl Hist Nat 8:819-833

Casanova J-P (1999) Chaetognatha. In: Boltovskoy D (ed) South Atlantic Zooplankton. Backhuys Publishers, Leiden, pp 13531374

David PM (1955) The distribution of Sagitta gazellae Ritter-Záhony. Discov Rep 27:235-278

David PM (1958a) The distribution of the Chaetognatha of the Southern Ocean. Discov Rep 29:199-228

David PM (1958b) A new species of Eukrohnia from the Southern Ocean with a note on fertilization. Proc Zool Soc Lond 131:597606

David PM (1964) The distribution of Antarctic chaetognaths. In: Carrick R, Holdgate M, Prevost J (eds) Biologie Antarctique. Hermann, Paris, pp 253-256

David PM (1965) The Chaetognatha of the Southern Ocean. In: Mieghen JV, Oye PV (eds) Biogeography and ecology in Antarctica. Junk Press, Hague, pp 296-323

Dawson JK (1968) Chaetognaths from the Arctic Basin, including the description of a new species of Heterokrohnia. Bull South Calif Acad Sci 67:112-124

Dilling L, Alldredge AL (1993) Can chaetognath fecal pellets contribute significantly to carbon flux? Mar Ecol Prog Ser 92:51-58. doi: $10.3354 /$ meps092051

Dinofrio EO (1973) Resultados planctologicos de la campana Oceantar I-1. Quetognatos. Contrib Inst Antarct Argent 154:1-62

Duró A, Gili J-M (2001) Vertical distribution and abundance of juvenile chaetognaths in the Weddell Sea (Antarctica). Polar Biol 24:66-69. doi:10.1007/s003000000181

Duró A, Sabatés A, Gili J-M (1999) Mesoscale spatial distribution of chaetognaths along hydrographic gradients in the South Scotia
Sea (Antarctica). Polar Biol 22:195-206. doi:10.1007/ s003000050410

Everitt BS, Landau S, Leesek M (2001) Cluster analysis. Oxford University Press, London, p 248

Fagetti EG (1968) New record of Eukrohnia bathyantarctica David 1958, from the Gulf of Mexico and Caribbean Sea. Bull Mar Sci 18:383-387

Fagetti EG (1972) Bathymetric distribution of chaetognaths in the South Eastern Pacific Ocean. Mar Biol 17:7-29

Froneman PW, Pakhomov EA (1998) Trophic importance of the chaetognaths Eukrohnia hamata and Sagitta gazellae in the pelagic system of the Prince Edward Islands (Southern Ocean). Polar Biol 19:242-249. doi:10.1007/s003000050241

Hagen W (1985) On distribution and population structure of Antarctic Chaetognatha. Meeresforsch 30:280-291

Johnson TB, Terazaki M (2003) Species composition and depth distribution of chaetognaths in a Kurashio warm-core ring and Oyashio water. J Plankton Res 25:1279-1289. doi:10.1093/plankt/fbg085

Johnson TB, Terazaki M (2004) Chaetognath ecology in relation to hydrographic conditions in the Australian sector of the Antarctic Ocean. Polar Biosci 17:1-15

Kapp H (1991a) Archeterokrohnia Casanova, 1986, a junior synonym of Heterokrohnia Ritter-Záhony, 1911 (Chaetognatha), with a review of the species of Heterokrohnia. Helgol Meeresunters 45:237-252. doi:10.1007/BF02365644

Kapp H (1991b) Some aspects of buoyancy adaptations of chaetognaths. Helgolander Meeresunters 45:263-267. doi:10.1007/ BF02365646

Kramp PL (1939) The Godthaab Expedition 1928. Chaetognatha. Medd Gronl 80:3-40

Kruse S (2009) Population structure and reproduction of Eukrohnia bathyantarctica and Eukrohnia bathypelagica, deep sea chaetognaths in the Lazarev Sea, Southern Ocean. Polar Biol. doi:10.1007/s00300-009-0633-2

O'Sullivan D (1982) A guide to the chaetognaths of the Southern Ocean and adjacent waters. Anare Res Notes 2:1-57

Øresland V (1990) Feeding and predation impact of the chaetognath Eukrohnia hamata in Gerlache Strait, Antarctic Peninsula. Mar Ecol Prog Ser 63:201-209. doi:10.3354/meps063201

Øresland V (1995) Winter population structure and feeding of the chaetognath Eukrohnia hamata and the copepod Euchaeta antarctica in Gerlache Strait, Antarctic Peninsula. Mar Ecol Prog Ser 119:77-86. doi:10.3354/meps 119077

Pakhomov EA, Perissinotto R, Froneman PW (1999) Predation impact of carnivorous macrozooplankton and micronekton in the Atlantic sector of the Southern Ocean. J Mar Syst 19:47-64. doi:10.1016/S0924-7963(98)00023-2

Pakhomov EA, Perissinotto R, McQuaid CD, Froneman PW (2000) Zooplankton structure and grazing in the Atlantic sector of the Southern Ocean in late austral summer 1993. Part 1. Ecological zonation. Deep Sea Res Part I Oceanogr Res Pap 47:1663-1686. doi:10.1016/S0967-0637(99)00122-3

Pearre S (1991) Growth and reproduction. In: Bone Q, Kapp H, Pierrot-Bults AC (eds) The biology of chaetognaths. Oxford University Press, Oxford, pp 61-75

Piatkowski U (1985) Distribution, abundance and diurnal migration of macrozooplankton in Antarctic surface waters. Meeresforsch 30:264-279

Pierrot-Bults AC, Nair VR (1991) Distribution patterns in chaetognatha. In: Bone Q, Kapp H, Pierrot-Bults AC (eds) The biology of chaetognaths. Oxford University Press, Oxford, pp 86-116

Ritter-Záhony R von (1911) Revision der Chätognathen. Deutsche Südpolar-Expeditionen 13. 8:1-71

Rottmann ML (1978) Ecology of recurrent groups of pteropods, euphausiids, and chaetognaths in the Gulf of Thailand and the South China Sea. Mar Biol 48:63-78. doi:10.1007/BF00390532 
Sameoto DD (1987) Vertical distribution and ecological significance of chaetognaths in the Arctic environment of Baffin Bay. Polar Biol 7:317-328. doi:10.1007/BF00293222

Schröder M, Fahrbach E (1999) On the structure and the transport of the eastern Weddell Gyre. Deep Sea Res Part II Top Stud Oceanogr 46:501-527. doi:10.1016/S0967-0645(98)00112-X

Sokal RR, Rohlf FJ (1981) Biometry. The principles and practice of statistics in biological research, 2nd edn. Freeman and company, San Francisco, p 859

Sullivan BK (1980) In situ feeding behaviour of Sagitta elegans and Eukrohnia hamata (Chaetognatha) in relation to the vertical distribution and abundance of prey at Ocean station "P". Limnol Oceanogr 25:317-326

Tchindonova YG (1955) Chaetognatha of the Kurile-Kamchatka trench. Tr Inst Okeanologii 12:298-310

Terazaki M (1989) Distribution of chaetognaths in the Australian sector of the Southern Ocean during the Biomass Sibex Cruise (KH-83-4). Proc NIPR Symp Polar Biol 2:51-60
Terazaki M (1991) Deep sea chaetognaths. In: Bone Q, Kapp H, Pierrot-Bults AC (eds) The biology of chaetognaths. Oxford University Press, Oxford, pp 117-121

Terazaki M (1996) Vertical distribution of pelagic chaetognaths and feeding of Sagitta enflata in the Central Equatorial Pacific. J Plankton Res 18:673-682. doi:10.1093/plankt/18.5.673

Thiel ME (1938) Die Chaetognathen-Bevölkerung des Südatlantischen Ozeans. Wissenschaftliche Ergebnisse der Deutschen Atlantischen Expedition "Meteor" 1925-1927. 13:1-110

Timofeev SF (1998) Reproduction of the chaetognath Eukrohnia hamata (Möbius 1875) in the Arctic Ocean. Rep Polar Mar Res 287:70-73

Timonin AG (1968) Distribution of chaetognaths in the Southern Ocean. Oceanology (Mosc) 8:702-709

Voronina NM (1968) The distribution of zooplankton in the Southern Ocean and its dependence on the circulation of water. Sarsia 34:277-284 